\title{
PROFIL KINERJA GURU PENDIDIKAN JASMANI SD NEGERI
}

\author{
Triyono \\ Universitas Terbuka UPBJJ-UT Yogyakarta \\ triyono@ut.ac.id
}

\begin{abstract}
This study aims to determine the results of peer and student assessment of the performance of physical education teachers (Penjas) Elementary School in Purworejo, Banyuurip and Kutoarjo associated with pedagogical, professional, personal and social. This article only discusses the pedagogical competence of the physical education teacher. The study design was a survey with data collection by distributing questionnaires to colleagues and students. The population is the entre physical education teacher at the elementary school in the area Purworejo, Banyuurip and Kutoarjo with a sample of 200 teachers were taken by random sampling technique. Questionnaires were returned as many as 164 copies. The collected data were then analyzed by using percentages to facilitate exposure and describe in narrative. The results showed that most of the peers judge that pedagogical competence of teachers in elementary schools in Region Penjas Purworejo, Banyuurip and Kutoarjo is good (88\%) or very good (29.2\%). While students assess their pedagogical competence Penjas teachers with excellent $33.9 \%, 16.8 \%$ good and $14.8 \%$ is good enough. .
\end{abstract}

Keywords: Elementary school, performance, physical education teachers

\begin{abstract}
ABSTRAK
Penelitian ini bertujuan untuk mengetahui hasil penilaian teman sejawat dan siswa terhadap kinerja guru pendidikan jasmani (Penjas) SD Negeri di Kabupaten Purworejo, Banyuurip dan Kutoarjo terkait dengan kompetensi pedagogik, profesional, kepribadian dan sosial. Artikel ini hanya membahas kompetensi pedagogik dari guru penjas. Desain penelitian adalah survey dengan teknik pengumpulan data melalui penyebaran kuesioner kepada teman sejawat dan siswa. Populasi adalah seluruh guru penjas di SD di Wilayah Purworejo, Banyuurip dan Kutoarjo dengan sampel sebanyak 200 guru yang diambil dengan teknik random sampling. Kuesioner yang kembali sebanyak 164 eksemplar. Data yang terkumpul kemudian dianalisis dengan menggunakan teknik persentase untuk memudahkan pemaparan dan mendeskripsikannya secara naratif. Hasil penelitian menunjukkan bahwa hampir sebagian besar teman sejawat menilai bahwa kompetensi pedagogik guru Penjas di SD di Wilayah Purworejo, Banyuurip dan Kutoarjo sudah baik (88\%) atau sangat baik $(29,2 \%)$. Siswa menilai kompetensi pedagogik guru Penjas mereka dengan sangat baik $33,9 \%$, baik $16,8 \%$ dan cukup baik $14,8 \%$.
\end{abstract}

Kata kunci: Guru pendidikan jasmani, kinerja, SD negeri

Perhatian yang sungguh-sungguh terhadap sumber daya manusia (SDM) dalam suatu organisasi makin meningkat karena produktivitas suatu organisasi banyak ditentukan oleh kinerja SDM (Ilyas dan Zuhaeri, 2004: 2). Indikator bangsa berkualitas sangat ditentukan oleh tingkat SDM nya, dan indikator SDM ditentukan oleh tingkat pendidikan masyarakatnya. Semakin tinggi sumber daya manusianya, semakin baik tingkat pendidikannya, dan demikian pula sebaliknya. Indikator tersebut sangat ditentukan oleh kinerja guru. 
Kinerja guru perlu terus-menerus ditingkatkan karena gurulah yang berada di garda terdepan dalam menciptakan kualitas SDM. Di tangan gurulah akan dihasilkan peserta didik yang berkualitas, baik secara akademis, keahlian, kematangan emosional, moral, dan spiritual. Dengan demikian, akan dihasilkan generasi masa depan yang siap hidup dengan tantangan zamannya. Oleh karena itu, diperlukan sosok guru yang mempunyai kualifikasi, kompetensi, dan dedikasi yang tinggi dalam menjalankan tugas profesionalnya.

Berkaitan dengan masalah kualifikasi, realita menunjukkan bahwa mutu guru di Indonesia dinilai masih sangat memprihatinkan.

Tabel 1. Data Kualifikasi Guru Secara Nasional

\begin{tabular}{ll}
\hline JUMLAH GURU & 2.607 .311 orang \\
\hline KUALIFIKASI & \\
Belum S-1 & 1.496 .721 orang (57\%) \\
S-1, S-2, S-3, dan D-IV & 1.110 .590 orang (43\%) \\
\hline
\end{tabular}

Sumber : Direktorat Jenderal Peningkatan Mutu Pendidik dan Tenaga

Kependidikan Kementerian Pendidikan Nasional 2010

Rendahnya profesionalitas guru di Indonesia dilihat dari kelayakan guru mengajar. Menurut Surya Dharma, Balitbang Depdiknas (2009), input guru di Indonesia sangat rendah. Guru-guru yang layak mengajar untuk tingkat Sekolah Dasar (SD) baik negeri maupun swasta ternyata hanya 28,94\%. guru Sekolah Menengah Pertama (SMP) negeri 54,12\%, swasta 60,99\%, guru Sekolah Menengah Atas (SMA) negeri 65,29\%, swasta 64,73\%, guru Sekolah Menengah Kejuruan (SMK) negeri $55,91 \%$, swasta $58,26 \%$.

Berdasarkan survei awal pada 16 Januari 2012, diketahui ungkapan klasik sebagian besar guru pendidikan jasmani (Penjas), yaitu kurangnya sarana prasarana (Sarpras) dan tidak adanya lapangan olahraga di sekolah dasar. Ketersediaan Sarana prasarana (peralatan olahraga), 39 responden (78\%) menyatakan sangat kurang, 26 responden (52\%) menyatakan tidak ada lapangan olahraga di SD dan, 20 responden (40\%) responden menjawab tidak ada alat olahraga yang sesuai. Selain alasan tidak adanya sarpras yang memadai, kesulitan-kesulitan yang dikemukakan para guru (berdasarkan hasil wawancara peneliti dengan guru-guru Penjas SD negeri) tersebut menunjukkan bahwa profesionalitas seorang guru penjas masih dipertanyakan. Benarkah mereka sudah bekerja dengan baik dan maksimal? Bagaimana dengan kinerjanya selama ini?

Menurut Fanan (2005: 12), melalui pendidikan, pengembangan budaya unggul dapat dilakukan. Kualitas pendidikan hanya dapat tercapai jika melalui penyelenggaraan pendidikan yang bermutu. Oleh karena itu, untuk menjamin tercapainya tujuan pendidikan yang bermutu guru harus berkualitas di bidangnya. Guru yang bermutu ialah guru yang memiliki kemampuan profesional dengan berbagai kapasitas sebagai pendidik. Studi Basic Education Quality (1992) dalam Suryadi (2001: 9) dinyatakan bahwa "guru yang bermutu ditentukan empat faktor utama, yaitu: (1) kemampuan profesional, (2) upaya profesional, (3) waktu yang tercurah untuk kegiatan profesional, dan (4) akuntabilitas."

Kondisi kualitas pembelajaran Penjas, olahraga dan kesehatan yang memprihatinkan di SD disebabkan oleh beberapa faktor, "di antaranya adalah terbatasnya kemampuan guru pendidikan jasmani, olahraga dan kesehatan" (Mutohir 2002: 16). Berbagai permasalahan tentang perilaku guru seperti tersebut, juga terjadi di wilayah Kabupaten Purworejo. Tidak hanya masalah kompetensi atau 
kinerja saja, tetapi juga permasalahan kualitas guru ditinjau dari aspek kualifikasi. tenaga kependidikan terutama guru pendidikan jasmani di sekolah dasar, masih banyak yang belum memenuhi kualifikasi yang dipersyaratkan sesuai undang-undang yakni sarjana (S1) dalam bidang yang relevan. Guru Penjas pada umumnya masih berijazah Diploma Dua (D2).

Kebijakan Pemerintah yang berkaitan dengan kualifikasi guru senantiasa berubah sesuai tuntutan zaman, yakni pada awalnya guru SD cukup berijazah SPG/SGO meningkat menjadi D2, dan sekarang minimal S1. Di bawah ini adalah data guru Penjas SD di Kabupaten Purworejo.

Tabel 2. Data Guru Penjas SD Negeri di Kabupaten Purworejo

\begin{tabular}{lcccccc}
\hline & \multicolumn{2}{c}{ PNS } & \multicolumn{2}{c}{ IJAZAH S1 } & \multicolumn{2}{c}{ SERTIFIKASI } \\
\cline { 2 - 7 } UPT/KEC. & Sudah & Belum & Sudah & Belum & Sudah & Belum \\
\cline { 2 - 7 } & 1 & 2 & 3 & 4 & 5 & 6 \\
\hline Bagelen & 21 & 2 & 9 & 14 & 11 & 12 \\
Banyuurip & 28 & 1 & 5 & 24 & 17 & 12 \\
Bener & 23 & 3 & 5 & 21 & 9 & 17 \\
Bruno & 21 & 2 & 14 & 9 & 7 & 16 \\
Butuh & 21 & 4 & 4 & 21 & 0 & 25 \\
Gebang & 30 & 0 & 12 & 18 & 8 & 22 \\
Kaligesing & 21 & 3 & 16 & 8 & 12 & 12 \\
Kemiri & 18 & 4 & 13 & 9 & 8 & 14 \\
Kutoarjo & 34 & 0 & 16 & 18 & 10 & 24 \\
Loano & 17 & 3 & 4 & 16 & 3 & 17 \\
Ngombol & 30 & 0 & 15 & 15 & 3 & 27 \\
Pituruh & 33 & 10 & 13 & 30 & 11 & 32 \\
Purwodadi & 32 & 0 & 15 & 17 & 13 & 19 \\
Purworejo & 46 & 4 & 15 & 35 & 13 & 37 \\
Grabag & 28 & 0 & 5 & 23 & 5 & 23 \\
Bayan & 27 & 1 & 12 & 16 & 20 & 8 \\
\hline
\end{tabular}

Kinerja guru mempunyai spesifikasi/kriteria tertentu. Kinerja guru dapat dilihat dan diukur berdasarkan spesifikasi/kriteria kompetensi yang harus dimiliki oleh setiap guru. Berdasarkan Peraturan Menteri Pendidikan Nasional Republik Indonesia Nomor 16 Tahun 2007 tentang Standar Kualifikasi Akademik dan Kompetensi Guru. Kinerja pendidik adalah perilaku atau respons yang memberi hasil yang mengacu kepada apa yang mereka kerjakan ketika ia menghadapi suatu tugas. Kinerja tenaga pendidik menyangkut semua kegiatan atau tingkah laku yang dialami tenaga pendidik (Yamin, Martinis dan Maisah, 2010: 87). Sementara itu istilah kompetensi berasal dari bahasa Inggris competence sama dengan being competent dan competent sama dengan having ability, power, authority, skill, knowledge, attitude, etc. Menurut Fullan (dalam Hamzah Uno, 2008: 62):

Competence is broad capacities as fully human attribute. Competence is supposed to include all "qualities of personal effectiveness that are required in the workplace"; it is certain that we have here a very diverse set of qualities indeed: attitudes, motives, interests, personal attunements of all kinds, perceptiveness, receptivity, openness, creativity, social skills generally, interpersonal maturity, kinds of personal identification, etc. - as well as knowledge, understandings, action and skills. 
Inti dari pengertian kompetensi menurut Fullan tersebut lebih cenderung pada apa yang dapat dilakukan seseorang/masyarakat daripada apa yang mereka ketahui (what people can do rather than what they know). Berdasarkan Permendiknas 16/2007 dan dalam UU No 14 Tahun 2005 tentang Guru dan Dosen pasal 10 dikemukakan bahwa kompetensi guru itu mencakup: (1) Kompetensi Pedagogik, (2) Kompetensi Sosial, (3) Kompetensi Kepribadian, dan (4) Kompetensi Profesional.

Kompetensi akademik dan kompetensi profesional seorang guru merupakan dua aspek yang terintegrasi, ibarat dua sisi pada sekeping mata uang, sehingga pembentukannya tidak dapat dipisahkan sebagaimana tersurat dalam ayat 1 dan 2 pasal 7 UU No. 14 Tahun 2005, serta pasal 29 PP No. 19/2005. Sehubungan dengan itu, maka keempat kompetensi yang telah diuraikan di atas, yaitu (1) kemampuan mengenal secara mendalam peserta didik SD yang hendak dilayani; (2) penguasaan bidang ilmu sumber bahan ajaran lima bidang studi di SD, baik dari segi disciplinary content knowledge, maupun dari segi pedagogical content knowledge; (3) kemampuan menyelenggarakan pembelajaran yang mendidik; serta (4) mengembangkan kemampuan profesional secara berkelanjutan, merupakan kompetensi akademik dari seorang guru SD. Selanjutnya, kompetensi profesional guru SD akan terbentuk melalui latihan penerapan kompetensi akademik tersebut dalam konteks otentik di SD melalui program pengalaman lapangan yang sistematis dan intensif. Oleh karena itu, demi integritas sertifikat profesi guru SD yang dianugrahkan, maka rujukan dasar yang digunakan dalam penyelenggaraan berbagai format pendidikan profesional guru SD serta asesmen penguasaan kompetensi profesional keguruan adalah sosok utuh kompetensi profesional guru.

Berdasarkan latar belakang tersebut maka artikel ini menguraikan hasil penelitian terkait penilaian teman sejawat dan siswa terhadap kinerja guru penjas SD Negeri di Kabupaten Purworejo ditinjau dari aspek kompetensi pedagogik. Pada profil kompetensi pedagogik ditujukan untuk mengungkap aspek kemampuan mengelola pembelajaran peserta didik. Seorang guru (khususnya guru Penjas) dikatakan berkompeten atau memiliki kompetensi pedagogik apabila guru tersebut memiliki kemampuan sebagai berikut.

a. Mengidentifikasi perkembangan kognitif peserta didik;

b. Mengidentifikasi potensi khusus peserta didik;

c. Mengidentifikasi bekal-ajar awal peserta didik;

d. Merancang pembelajaran yang inovatif berdasarkan strategi yang dipilih;

e. Merancang strategi pembelajaran yang sesuai dengan karateristik peserta didik, kompetensi yang ingin dicapai, dan materi ajar;

f. Menata (setting) pembelajaran;

g. Melaksanakan pembelajaran yang kondusif;

h. Menggunakan dan mempersiapkan jaringan komputer yang dapat diakses peserta didik;

i. Melaksanakan penilaian proses dan hasil belajar secara berkesinambungan dengan berbagai metode;

j. Menganalisis hasil penilaian proses dan hasil belajar untuk menentukan tingkat ketuntasan belajar; serta

k. Menfasilitasi peserta didik untuk mengembangkan berbagai potensi dalam rangka aktualisasi diri. 
Manfaat dari hasil penelitian ini bagi: (1) guru pendidikan jasmani, untuk self evaluation yaitu untuk mengetahui letak kelemahan atau kekurangan kualitas pribadinya, dengan mengetahui kekurangan dan kelemahan kita dapat membangun kembali "konstruksi" berpikir dan berperilaku untuk kemudian dapat memperbaiki dan meningkatkan profesionalisme sebagai guru Penjas di masa depan, (2) Institusi/pengguna, menjadi bahan refleksi untuk meningkatkan pelayanan pendidikan yang profesional kepada masyarakat, (3) Pemerintah, memberikan balikan dalam hal menentukan kebijakan, khususnya terkait dengan program sertifikasi guru Penjas dan guru pada umumnya.

\section{METODE PENELITIAN}

Desain penelitian ini dilakukan dengan menggunakan teknik survei. Populasi dalam penelitian ini adalah seluruh guru penjas SD negeri di Kementerian Pendidikan dan Kebudayaan Purworejo, Banyuurip dan Kutoarjo, yaitu sebanyak 339 orang. Sampel adalah guru Penjas SD negeri di Kementerian Pendidikan dan Kebudayaan Purworejo Banyuurip dan Kutoarjo sebanyak 200 orang dan responden adalah teman sejawat dan siswa dari sampel sebanyak 200 responden. Sampel diambil dengan teknik acak sederhana . Penelitian ini dilaksanakan di wilayah Kementerian Kebudayaan Kabupaten Purworejo, Banyuurip dan Kutoarjo Provinsi Jawa Tengah dan waktu pelaksanaan mulai 31 Maret 2012 sampai dengan akhir Oktober 2012. Data dikumpulkan dengan menyebarkan kuesioner terhadap teman sejawat dan siswa kelas 5 dari guru Penjas. Namun dari 200 kuesioner yang disebarkan, yang kembali sebanyak 164 eksemplar. Pengolahan data menggunakan persentase yang kemudian dideskripsikan secara naratif agar lebih mudah memaparkan data yang terkumpul.

\section{HASIL DAN PEMBAHASAN}

\section{Kesungguhan dalam Mempersiapkan Pembelajaran}

Penilaian teman sejawat dan penilaian siswa terhadap kinerja guru dalam mempersiapkan pembelajaran dapat dilihat dalam Gambar 1 dan Gambar 2.
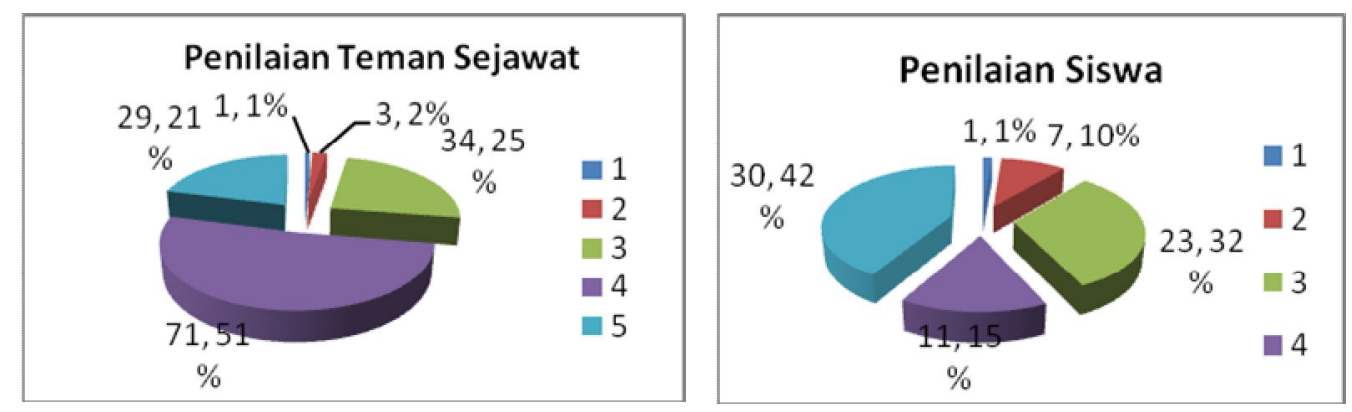

Gambar 1. dan Gambar 2.

Penilaian teman sejawat dan penilaian siswa terhadap kinerja guru dalam mempersiapkan pembelajaran

Data tersebut menggambarkan bahwa berdasarkan penilaian sejawat guru Penjaskes di wilayah Purworejo, Banyuurip dan Kutoarjo memiliki kesungguhan dalam mempersiapkan pembelajaran. Hal ini ditandai dengan pendapat sejawat yang menyatakan sangat baik sebesar $29 \%$ 
dan menyatakan baik sebesar 51\%, 34\% menyatakan biasa saja dan sisanya sebesar $3 \%$ menyatakan tidak baik atau sangat tidak baik. Pendapat sejawat tersebut agak berbeda dengan pendapat siswa yang menyatakan guru penjas sangat baik dalam kesungguhan mempersiapan pembelajaran sebesar $42 \%$, baik $15 \%$, biasa saja $32 \%$, tidak baik dan sangat tidak baik sebesar $11 \%$. Data itu juga menunjukkan bahwa antara sejawat dan siswa terdapat perbedaan dalam menilai kesiapan guru.

\section{Keteraturan dan Ketertiban Penyelenggaraan Pembelajaran}

Penilaian teman sejawat dan penilaian siswa terhadap kinerja guru dalam hal keteraturan dan ketertiban pembelajaran dapat dilihat dalam Gambar 3 dan Gambar 4.
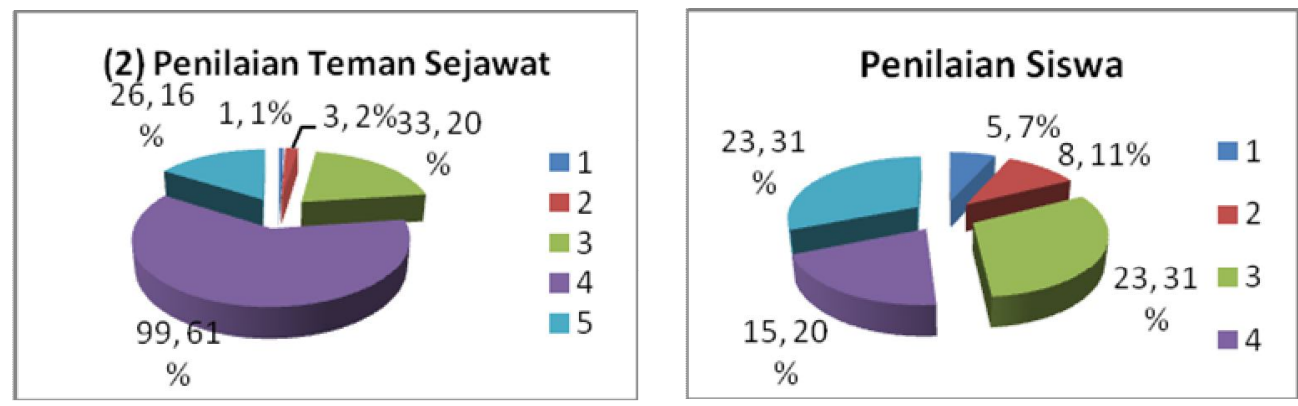

Gambar 3. dan Gambar 4.

Penilaian teman sejawat dan penilaian siswa terhadap kinerja guru dalam hal keteraturan dan ketertiban pembelajaran

Data tersebut menggambarkan bahwa menurut pendapat sejawat dan siswa dalam hal keteraturan dan ketertiban penyelenggaraan pembelajaran masih belum cukup baik atau biasa saja. Hal ini terlihat dari pendapat keduanya sebesar lebih dari 24\%. Selain itu, 19\% siswa berpendapat bahwa guru-guru olah raga di sekolah mereka tidak baik dalam ketertiban penyelenggaraan pembelajarannya. Meskipun sebagian besar (51-77 \%) siswa dan sejawat menyatakan bahwa guruguru olah raga di SD sangat baik dan baik dalam ketertiban dan keteraturan penyelenggaraan pembelajaran.

\section{Kemampuan Mengelola Kelas}

Penilaian teman sejawat dan penilaian siswa terhadap kinerja guru dalam hal kemampuan mengelola kelas dapat dilihat dalam Gambar 5 dan Gambar 6.
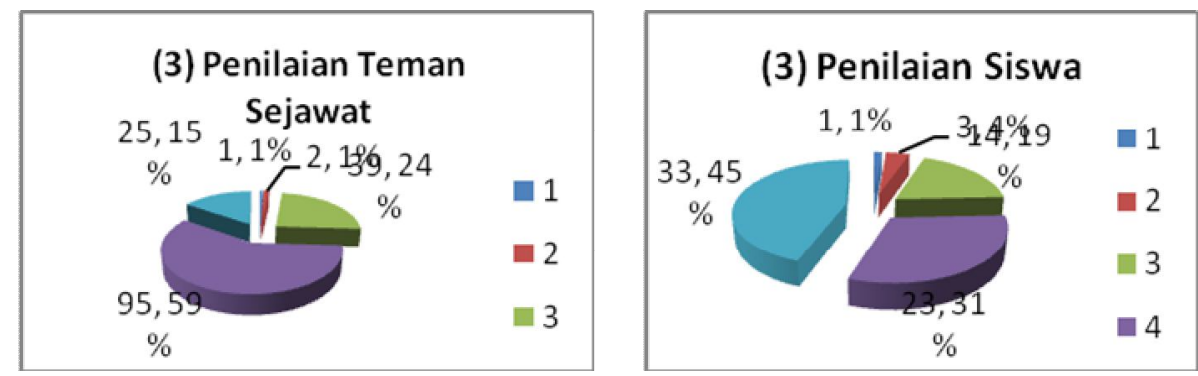

Gambar 5. dan Gambar 6.

Penilaian teman sejawat dan penilaian siswa terhadap kinerja guru dalam mengelola kelas 
Mengenai kemampuan mengelola kelas, data yang terkumpul menunjukkan bahwa sebagian besar siswa (68\%) dan teman sejawat (74\%) menyatakan setuju dan sangat setuju bahwa guru-guru olah raga di SD dapat mengelola kelas dengan baik dan sangat baik. Meskipun demikian ada 5\% siswa yang menyatakan bahwa guru olah raga di sekolahnya kurang baik dalam mengelola kelas.

\section{Kedisiplinan dan Kepatuhan Terhadap Aturan Akademik}

Penilaian teman sejawat dan penilaian siswa terhadap kinerja guru dalam hal kedisiplinan dan kepatuhan terhadap aturan akademik dapat dilihat dalam Gambar 7 dan Gambar 8.
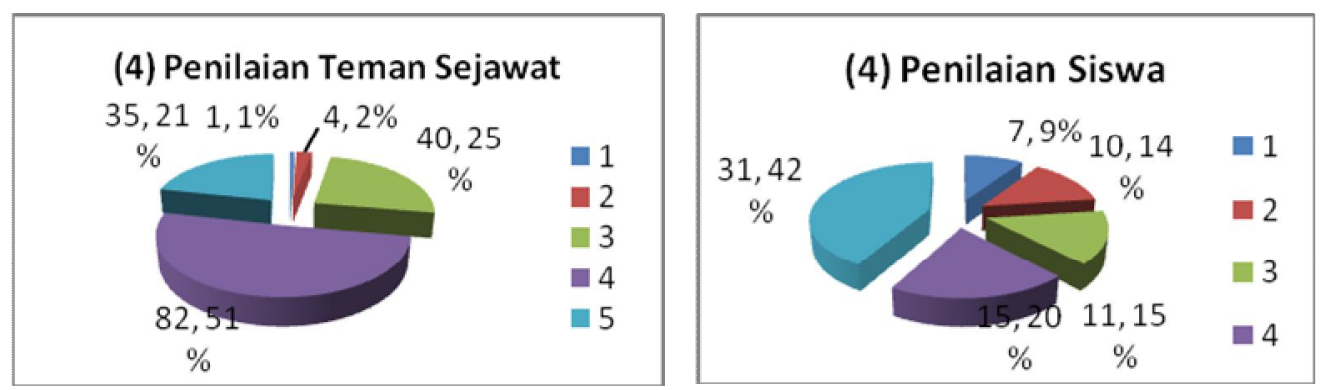

Gambar 7. dan Gambar 8.

Penilaian teman sejawat dan penilaian siswa terhadap kinerja guru dalam kedisiplinan dan kepatuhan akademik

Dalam hal kedisiplinan dan kepatuhan terhadap aturan akademik, cukup banyak siswa (23\%) yang menyatakan bahwa guru olah raga di sekolah mereka sangat kurang baik dan kurang baik sedangkan $15 \%$ diantaranya menyatakan biasa saja. Hal ini mengindikasikan bahwa menurut siswa banyak juga guru olah raga yang tidak disiplin atau tidak patuh, meskipun data ini tidak menggali lebih dalam, disiplin atau kepatuhan dalam hal apa. Berbeda dengan pendapat siswa tersebut, ternyata sebagian besar teman sejawat (72\%) dan sebagian besar siswa (62\%) berpendapat bahwa guru olah raga di SD memiliki kedisiplinan yang tinggi dan sangat tinggi.

\section{Penguasaan Media dan Teknologi Pembelajaran}

Penilaian teman sejawat dan penilaian siswa terhadap kinerja guru dalam hal penguasaan media dan teknologi pembelajaran dapat dilihat dalam Gambar 9 dan Gambar 10.
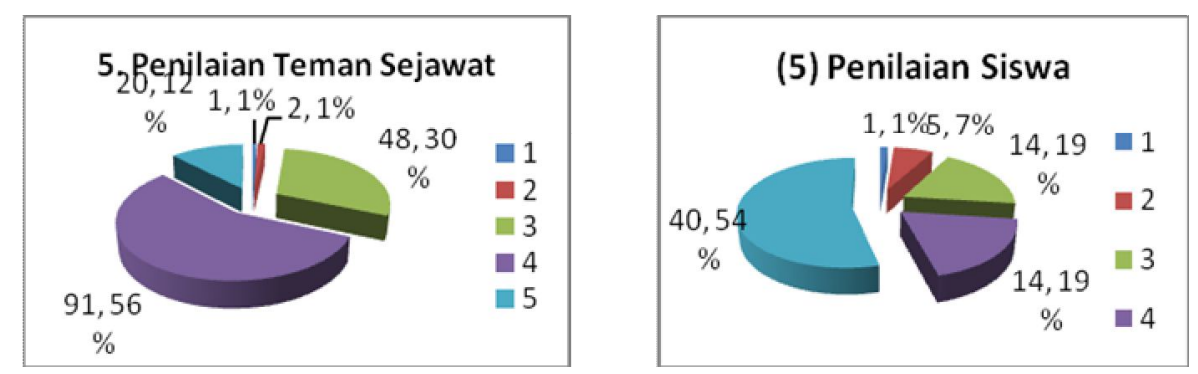

Gambar 9. dan Gambar 10.

Penilaian teman sejawat dan penilaian siswa terhadap kinerja guru dalam penguasaan media dan teknologi pembelajaran 
Secara umum data tersebut menggambarkan bahwa baik teman sejawat maupun para siswa berpendapat bahwa guru pendidikan jasmani atau guru olah raga di SD wilayah Purworejo,

Banyuurip dan Kutoarjo memiliki kemampuan penguasaan media dan teknologi pembelajaran sangat baik dan baik, yaitu sebesar 68\% (teman sejawat) dan 72\% (siswa). Sementara itu yang menganggap bahwa penguasaannya hanya biasa saja cukup banyak juga yaitu $30 \%$ (teman sejawat) dan 19\% (siswa). Sebagian kecil teman sejawat dan siswa menganggap bahwa penguasaan media dan teknologi pembelajaran rendah atau sangat rendah, yaitu hanya $2 \%$ dan $8 \%$ saja.

\section{Kemampuan Melaksanakan Penilaian Prestasi Belajar Peserta Didik}

Penilaian teman sejawat dan penilaian siswa terhadap kinerja guru dalam melaksanakan penilaian prestasi belajar peserta didik dapat dilihat dalam Gambar 11 dan Gambar 12.
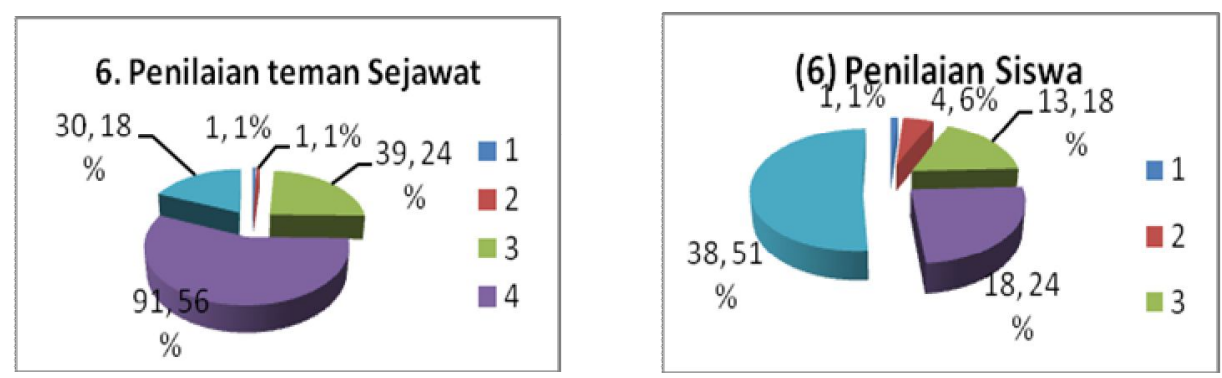

Gambar 11 dan Gambar 12.

Penilaian teman sejawat dan penilaian siswa terhadap kinerja guru dalam melaksanakan penilaian prestasi belajar peserta didik

Data tersebut menunjukkan bahwa sebagian besar teman sejawat (74\%) dan siswa (75\%) menyatakan bahwa guru-guru Penjas di SD memiliki kemampuan yang baik dan sangat baik dalam melaksanakan penilaian prestasi belajar peserta didiknya. Meskipun ada diantara mereka yang berpendapat bahwa ada guru penjas yang tidak memiliki kemampuan yang baik dalam melaksanakan penilaian terhadap peserta didiknya, yaitu sebesar $7 \%$ (siswa) dan $2 \%$ (teman sejawat. Ada 18\% (siswa) dan 24\% (teman sejawat) yang menyatakan bahwa kemampuan guru dalam melaksanakan penilaian adalah biasa saja.

\section{Objektivitas Dalam Penilaian Terhadap Peserta Didik}

Penilaian teman sejawat dan penilaian siswa terhadap kinerja guru dalam objektivitas penilaian peserta didik dapat dilihat dalam Gambar 13 dan Gambar 14.
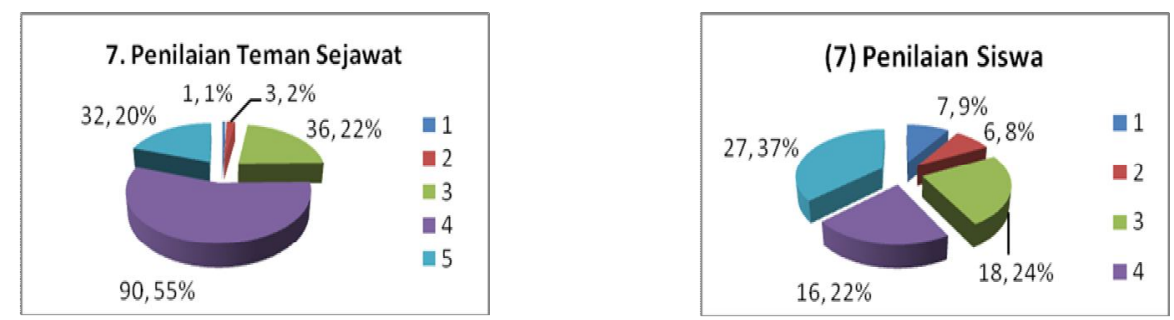

Gambar 13 dan Gambar 14.

Penilaian teman sejawat dan penilaian siswa terhadap kinerja guru dalam objectivitas penilaian peserta didik 
Menurut teman sejawat (75\%) guru penjas di SD memiliki objektivitas yang tinggi dan sangat tinggi dalam penilaian terhadap peserta didik, namun menurut siswa hanya 59\% saja guru Penjas yang objektif dalam menilai mereka. Menurut pendapat keduanya tidak berbeda jauh yang objektivitasnya biasa saja yaitu 22\% (teman sejawat) dan 24\% (siswa). Bagi siswa, cukup banyak guru penjas di SD yang tidak objektif dalam menilai yaitu sebesar 17\% namun data ini tidak menggali lebih dalam, apa alasan siswa menyatakan bahwa guru Penjas mereka tidak objektif dalam menilai.

\section{Kemampuan Membimbing Peserta Didik}

Penilaian teman sejawat dan penilaian siswa terhadap kinerja guru dalam kemampuan membimbing peserta didik dapat dilihat dalam Gambar 15 dan Gambar 16.
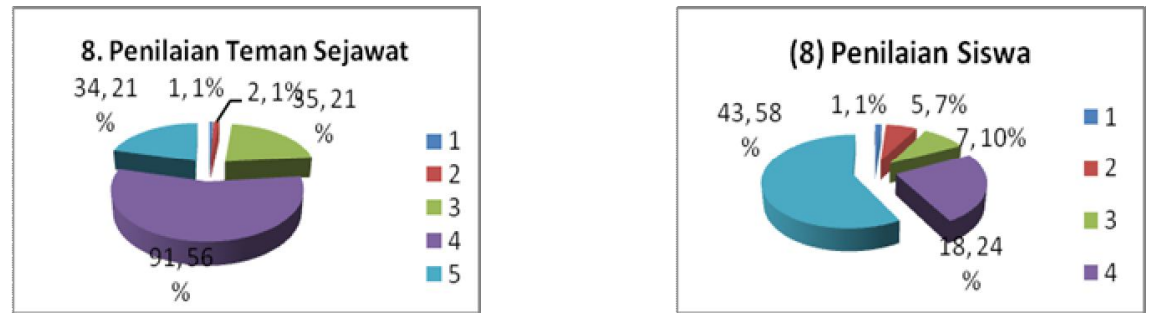

Gambar 15 dan Gambar 16.

Penilaian teman sejawat dan penilaian siswa terhadap kinerja guru dalam kemampuan membimbing peserta didik

Kemampuan membimbing siswa, menurut sejawat guru Penjas di wilayah sampel menunjukkan kemampuan yang sangat baik dan baik. Pendapat ini diberikan oleh $77 \%$ responden. Sementara itu yang menyatakan tidak baik hanya $2 \%$ responden. Sisanya menyatakan cukup atau biasa saja. Sementara itu, pendapat siswa (82\%) menyatakan bahwa guru Penjas mereka sangat baik dan baik dalam membimbing siswa-siswanya. Hanya5 \% responden siswa yang menyatakan tidak baik.

\section{Berpersepsi Positif Terhadap Kemampuan Peserta Didik}

Penilaian teman sejawat dan penilaian siswa tentang persepsi guru terhadap peserta didik dapat dilihat dalam Gambar 17 dan Gambar 18.
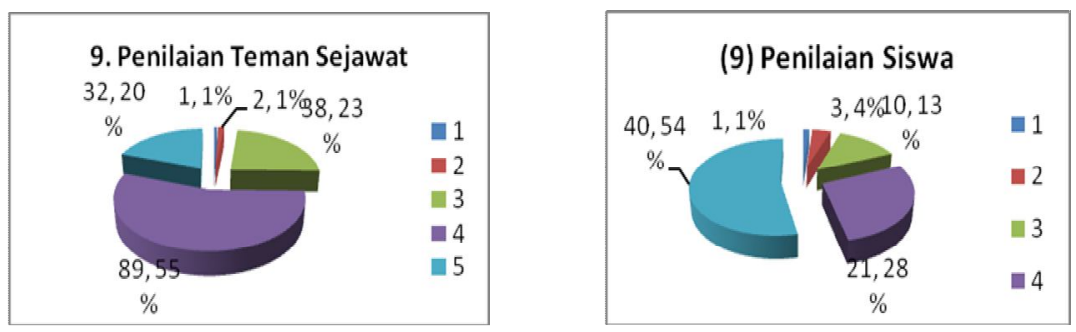

Gambar 17 dan Gambar 18.

Penilaian teman sejawat dan penilaian siswa tentang persepsi guru terhadap peserta didik

Berdasarkan data di atas menunjukkan bahwa guru Penjas memiliki persepsi positif terhadap kemampuan peserta didik sangat baik, 20\% sejawat menyatakan hal itu. 55\% responden menyatakan baik, $23 \%$ sejawat menyatakan cukup. Hanya $1 \%$ sejawat menyatakan bahwa guru 
Penjas tidak dan sangat tidak berpersepsi positif terhadap kemampuan peserta didiknya. Sedangkan 54\% penilaian siswa menyatakan guru Penjas mereka berpersepsi positif sangat tinggi terhadap mereka, 28\% siswa menyatakan tinggi dan 13\% siswa menyatakan persepsi positif guru Penjas terhadap peserta didik kategori cukup. Hanya $1 \%$ siswa yang menyatakan sangat kurang dan $4 \%$ lainnya siswa menyatakan kurang/rendah.

Secara keseluruhan hasil penilaian teman sejawat dan siswa pada kompetensi pedagogik guru Penjas di SD di Wilayah Kabupaten Purworejo dapat dilihat pada Tabel 3.

Tabel 3. Rangkuman Hasil Penilaian Teman Sejawat dan Siswa Terhadap Kompetensi Pedagogik Guru Penjas

\begin{tabular}{|c|c|c|c|c|c|c|c|c|c|c|}
\hline \multirow{3}{*}{$\begin{array}{c}\text { Aspek } \\
\text { yang Dinilai }\end{array}$} & \multicolumn{10}{|c|}{ SKOR (dalam \%) } \\
\hline & \multicolumn{2}{|c|}{1} & \multicolumn{2}{|c|}{2} & \multicolumn{2}{|c|}{3} & \multicolumn{2}{|c|}{4} & \multicolumn{2}{|c|}{5} \\
\hline & TS & $\mathrm{S}$ & TS & $\mathrm{S}$ & TS & S & TS & $\mathrm{S}$ & TS & $\mathrm{S}$ \\
\hline 1 & 1 & 1 & 3 & 7 & 34 & 23 & 71 & 11 & 29 & 30 \\
\hline 2 & 1 & 5 & 3 & 8 & 33 & 23 & 99 & 15 & 26 & 23 \\
\hline 3 & 1 & 1 & 2 & 3 & 39 & 14 & 95 & 23 & 25 & 33 \\
\hline 4 & 1 & 7 & 4 & 10 & 40 & 11 & 82 & 15 & 35 & 31 \\
\hline 5 & 1 & 1 & 2 & 5 & 48 & 14 & 91 & 14 & 20 & 40 \\
\hline 6 & 1 & 1 & 1 & 4 & 39 & 13 & 91 & 18 & 30 & 38 \\
\hline 7 & 1 & 7 & 3 & 6 & 36 & 18 & 90 & 16 & 32 & 27 \\
\hline 8 & 1 & 1 & 2 & 5 & 35 & 7 & 91 & 18 & 34 & 43 \\
\hline 9 & 1 & 1 & 2 & 3 & 38 & 10 & 89 & 21 & 32 & 40 \\
\hline Jumlah & 9 & 25 & 22 & 51 & 342 & 133 & 799 & 151 & 263 & 305 \\
\hline Rerata & 1 & 2,78 & 2,44 & 5,67 & 38 & 14,8 & 88,8 & 16,8 & 29,2 & 33,9 \\
\hline \multicolumn{11}{|c|}{ Keterangan: } \\
\hline \multicolumn{11}{|c|}{$1=$ sangat tidak baik/sangat rendah/tidak pernah $\quad$ TS = Teman Sejawat $\quad S=$ Siswa } \\
\hline \multicolumn{11}{|c|}{$2=$ tidak baik/rendah } \\
\hline \multicolumn{11}{|c|}{3 = biasa/cukup } \\
\hline \multicolumn{11}{|c|}{$4=$ baik/tinggi } \\
\hline \multicolumn{11}{|c|}{$=$ sangat bai } \\
\hline
\end{tabular}

Secara keseluruhan, hasil penilaian terhadap guru Penjas di SD di wilayah Kabupaten Purworejo menunjukkan dalam setiap komponen kompetensi pedagodik, teman sejawat menilai baik atau tinggi yaitu sebanyak $88,8 \%$, sangat baik $(29,2 \%)$ dari jumlah responden. Sedangkan siswa menilai kompetensi pedagogik guru Penjas mereka dengan sangat baik 33,9\%, baik $16,8 \%$ dan cukup baik $14,8 \%$.

\section{PENUTUP}

Berdasarkan hasil penelitian yang telah dilakukan, tampak bahwa hasil penilaian teman sejawat menunjukkan bahwa guru Penjas di wilayah Purworejo, Banyuurip dan Kutoarjo memiliki kompetensi pedagogik yang baik dan sangat baik, yaitu sebesar $88,8 \%$ dan $29,2 \%$. Responden yang menilai cukup baik, tidak baik atau kurang baik hanya kurang dari $10 \%$ saja. Penilaian peserta didik atau siswa menunjukkan bahwa siswa yang menganggap guru mereka sangat baik hanya sekitar 33,9\%, menilai baik hanya sebanyak 16,8\% siswa dan menilai cukup baik sebanyak 14,8\%. Sisanya menilai kurang baik atau tidak baik. Hasil ini belum dapat dianalisis lebih baik mengapa hanya sedikit anak didik yang menilai guru mereka dengan baik atau sangat baik, dan mengapa hampir semua teman sejawat menilai baik dan sangat baik terhadap kinerja guru penjas di SD di 
Wilayah Purworejo, Banyuurip dan Kutoarjo. Rekomendasi yang bisa disampaikan terkait hasil penilaian ini adalah bahwa guru penjas di SD di Wilayah Purworejo, Banyuurip dan Kutoarjo harus terus meningkatkan kinerjanya dalam beberapa aspek kompetensi, terutama kompetensi pedagogiknya karena penilaian siswa masih belum optimal.

\section{REFERENSI}

Dharma, S. (2009). Pendidik dan tenaga kependidikan menghadapi era global. Jakarta: Direktorat Jenderal Peningkatan Mutu Pendidik dan Tenaga Kependidikan, Departemen Pendidikan Nasional.

Fanan, F.A. (2005). Indonesia Memerlukan Budaya Organisasi. Diambil tanggal 2 Februari 2011 dari: http://bataviase.co.id/detailberita-10376825.html.

llyas, Y. dan Zuhaeri, A. (2004). Pengembangan Sistem Penilaian Kinerja Sumber Daya Manusia Pada Institut Pendidikan Tinggi Jarak Jauh. Indonesian journal of open and distance learning, Vol. 5 (1). Pusat Studi Indonesia, Lembaga Penelitian - Universitas Terbuka.

Suryadi, A. (2001). Menyoal mutu profesi guru. Jakarta: Kompas Media Nusantara.

Undang-undang Republik Indonesia Nomor 14 Tahun 2005 tentang Guru dan Dosen. Yogyakarta: Pustaka Pelajar.

Uno, H.B. (2008). Profesi kependidikan, problema, solusi, dan reformasi pendidikan di Indonesia. Jakarta: Bumi Aksara.

Yamin, M. \& Maisah. (2010). Standarisasi kinerja guru. Jakarta: Gaung Persada. 